\title{
ДИДАКТИЧНІ УМОВИ ФОРМУВАННЯ ПРИРОДОЗНАВЧОЇ КОМПЕТЕНТНОСТІ УЧНІВ ПОЧАТКОВИХ КЛАСІВ В УМОВАХ ІНКЛЮЗИВНОГО НАВЧАННЯ
}

канд. біол. наук, дои. Голуб Н. П., канд. біол. наук, дои. Голуб В. М.

Украйна, м. Умань, Уманський державний педагогічний університет імені Павла Тичини

DOI: https://doi.org/10.31435/rsglobal_ws/30042019/6479

\section{ARTICLE INFO}

Received: 22 February 2019

Accepted: 13 April 2019

Published: 30 April 2019

\section{KEYWORDS}

competence,

competency education, natural competence, competence approach, junior schoolchildren, inclusive education.

\begin{abstract}
The article deals with the formation peculiarities of natural science competence of elementary school students. The definitions of "competency" and "competence" are specified. The literary analysis indicated a lack of study of the investigated problem in the context of educational reform. Didactic conditions for the formation of natural science competence in conditions of inclusive education are determined.

The emphasis is focused on pedagogical technologies that involve individualization, differentiation and integration of learning.

Integrated lessons contribute to the formation of substantive and interdisciplinary key competencies. In 1-2 classes the formation of natural science competence should be based on an integrated-subject basis with the predominance of game techniques. In 3-4 classes the formation of natural science competence should be based on an integrated-subject basis with the predominance of means of individualization and differentiation.
\end{abstract}

Citation: Голуб Н. П., Голуб В. М. (2019) Dydaktychni Umovy Formuvannia Pryrodoznavchoi Kompetentnosti Uchniv Pochatkovykh Klasiv v Umovakh Inkliuzyvnoho Navchannia. World Science. 4(44), Vol.3. doi: 10.31435/rsglobal_ws/30042019/6479

Copyright: () 2019 Голуб Н. П., Голуб В. М. This is an open-access article distributed under the terms of the Creative Commons Attribution License (CC BY). The use, distribution or reproduction in other forums is permitted, provided the original author(s) or licensor are credited and that the original publication in this journal is cited, in accordance with accepted academic practice. No use, distribution or reproduction is permitted which does not comply with these terms.

Постановка проблеми. Характерною тенденцією реформування сучасної освіти в Україні є спрямованість на покращення іiі якості, орієнтація на всебічний розвиток і підвищення рівня освіченості особистості. Важливою складовою загальної освіти кожної людини $\epsilon$ природнича освіта. У іï зміст закладена система природничих знань, яка необхідна для адекватного світосприйняття та уявлення про сучасну природничо-наукову картину світу, опанування науковим стилем мислення, усвідомлення способів діяльності і ціннісних орієнтацій, що дають змогу безпечно жити у високотехнологічному суспільстві та цивілізовано взаємодіяти з природним довкіллям.

На сучасному етапі розвитку українського суспільства перед загальноосвітньою школою стоїть завдання виховати особистість, здатну до активної життєвої творчої діяльності. Така особистість зуміє правильно обрати свій шлях у житті, опираючись на власні можливості та здібності. Вона буде ставити перед собою завдання самовдосконалення, саморозвитку та самоосвіти. На сьогодні ставляться високі вимоги до професійної діяльності людини, тому конкурентоспроможність та компетентність стануть запорукою іiі успіху в різних сферах діяльності.

Аналіз актуальних досліджень. Аналіз сучасних досліджень педагогів, філософів і соціологів свідчить про економічну, соціальну та демографічну значущість проблеми формування компетентностей молодших школярів. Проблеми формування компетентностей учнів різного віку досліджували І. Д. Бех, Н.М.Бібік, А. М. Богуш, В. А Болотов, Л. С. Ващенко, В. В. Вербицький, 
Л. Г. Савлучинська, О. Я. Савченко, А. В. Хуторський, які встановили, що сформовані та закріплені у молодшому шкільному віці компетентності дозволяють особистості успішно адаптуватися у динамічному суспільстві, що особливо важливо у XXI столітті. Основні питання формування і розвитку природознавчої компетентності молодших школярів розглядали О. П. Грошовенко, О. М. Можаєва, Л. А. Присяжнюк, Н. М. Редчиць, Л. Г. Савлучинська та інші $[2 ; 5 ; 7 ; 8]$. В умовах становлення Нової української школи та інклюзивного навчання означена проблема не втрачає своєї актуальності.

Мета статті - розглянути дидактичні умови формування природознавчої компетентності в учнів молодшого шкільного віку в умовах інклюзії.

Виклад основного матеріалу. Поняття «компетентнісна освіта» виникло у США. Його основою було вивчення педагогічного досвіду передових учителів. Термін «компетентнісний підхід» запроваджений американськими вченими в 60 -х роках минулого століття, а в 70 -х роках він був внесений до професійних освітніх програм США та у 80-х роках - до професійних підготовчих програм Німеччини та Великобританії [10].

Свій подальший розвиток компетентнісний підхід знайшов у програмі «Визначення та відбір компетентностей: теоретичні й концептуальні засади» («DeSeCo») в рамках Федерального статистичного департаменту Швейцарії та Національного центру освітньої статистики США й Канади [9]. Ми підтримуємо думку про те, що компетентнісний підхід спрямованість освітнього процесу на формування й розвиток ключових і предметних компетентностей особистості.

У сучасних умовах роль компетенцій та компетентностей розглядають у різних контекстах:

- компетентність як засіб оновлення змісту освіти у відповідь на соціально-економічну реальність, яка швидко змінюється (Т. М. Ковальова, О. В. Овчарук, Н. Ф. Радсонова, І. Д. Фрумін);

- компетентність як узагальнена умова здатності людини ефективно діяти за межами навчальних сюжетів і навчальних ситуацій (В. А. Болотов, В. В. Сериков, Л. В. Сокань);

- компетентність як можливість перенесення здібностей в умови, які відрізняються від тих, у яких ця компетентність первинно виникла (В. В. Башев, І. Г. Срмакова, Л. В. Сокань);

- компетентність як готовність спеціаліста включитися у певний вид діяльності (А. М. Аронов, О. В. Кугай);

- компетентність як засіб підготовки до майбутньої професійної діяльності (В. О. Калінін В. Т. Лозовецька, А. К. Маркова, Н. В. Нагорна, Л. О. Стояніна, Г. П. Щедровицький);

- компетентність як якість особистості, iï певне надбання, що грунтується на знаннях, досвіді, моральних засадах і проявляється у критичний момент за рахунок вміння знаходити зв'язок між ситуацією та знаннями, у прийнятті адекватних рішень нагальної проблеми (П. Ф. Драккер, М. С. Головань, С. В. Лейко, С. С. Шишов).

Переважна більшість авторів під компетенцією розуміють певну сферу діяльності, наперед визначену систему питань, щодо яких особистість повинна володіти спеціально структурованим набором знань, умінь, навичок та власного до них ставлення, що набувається у процесі навчання $[1 ; 2 ; 4]$.

У XXI столітті проблеми раціонального використання природних ресурсів і збереження навколишнього середовища значно загострилися та мають глобальний характер, тому вимагають від людства кардинально нових підходів до природокористування. Це, в свою чергу, зумовлює необхідність конкретних змін у соціальних та економічних відносинах. Світова спільнота повинна спрямувати силу свого інтелекту на глибоке, всебічне вивчення всіх складових природного середовища, відновити порушену природну рівновагу, вибрати способи раціонального використання, збереження та примноження біоресурсів, відмовитись від споживацького ставлення до природи, переосмислити систему цінностей.

Особливості розвитку сучасного постіндустріального інформаційного суспільства зумовлюють необхідність формування базових компетентностей протягом усього активного життя людини. Ключові освітні компетентності, виконуючи міжпредметні і метапредметні функції, повинні формуватися на уроках з усіх навчальних предметів. Тому початкова школа повинна постійно розв’язувати завдання, які сприяють:

- глибокому засвоєнню молодшими школярами природничих знань;

- вільному оперуванню ними;

- застосуванню засвоєних знань у соціалізації та творчій самореалізації;

- розширенню та поглибленню свого пізнавального досвіду;

- формуванню екологічного мислення й поведінки [3]. 
Базисною основою подальшого успішного навчання молодших школярів в основній школі $є$ набуття ними загальнонавчальних та цільових компетентностей діяльності. Формування ключових компетентностей реалізується в освітніх галузях i навчальних предметах. При цьому кожний предмет забезпечує реалізацію тих складових змісту ключових компетентностей, для формування яких має необхідні умови. Особливо важлива роль у формуванні багатьох компетентностей належить природничій освітній галузі, навчальний матеріал якої має інтегрований зміст.

На основі Державного стандарту розроблена програма навчального предмета «Природознавство». Зміст програми передбачає розвиток системних уявлень про цілісність природи, утвердження принципів сталого розвитку ефективної безпечної, природоохоронної поведінки в довкіллі, формування наукового мислення та культури дослідження. Принцип побудови навчальної програми забезпечує наступність і неперервність навчально-виховного процесу у початковій та середній загальноосвітній школі.

Метою природничої освітньої галузі $є$ формування природознавчої компетентності учнів шляхом засвоєння системи інтегрованих знань про природу, способів навчальнопізнавальної діяльності, розвитку ціннісних орієнтацій у різних сферах життєдіяльності та природоохоронної практики.

Предметна природознавча компетентність - особистісна риса, що характеризує здатність учнів розв'язувати доступні соціально й особистісно значущі практичні та пізнавальні проблемні задачі, пов'язані з реальними об'єктами природи у сфері відносин «людина - природа» [3].

О. П. Грошовенко наголошує, що природознавча компетентність - це не тільки специфічні предметні вміння, а й конкретні, життєві навички, необхідні людині будь-якої професії та віку. До системи природознавчої компетентності автор відносить екологічну, інформаційну, аксіологічну, просторову та логічну компетентності [2].

Для успішного формування природознавчої компетентності молодших школярів вивчення природознавства у початковій школі повинне орієнтуватися на компетентнісно орієнтований підхід 3 використанням сучасних освітніх технологій (розвиток критичного мислення та креативності, проблемний підхід, упровадження проектних технологій). Фронтальні та індивідуальні форми роботи повинні поєднуватися 3 колективною діяльністю (парною та груповою роботою) із застосуванням інноваційних методик, використанням інформаційно-комунікаційних засобів. У процесі пізнання природи відбувається всебічний розвиток особистості учнів, розвиваються морально-етичні якості, формуються навички природоохоронної діяльності [6].

Аналіз навчальних програм та підручників природничої освітньої галузі засвідчує їі значні можливості у формуванні в учнів початкових класів базових і ключових освітніх компетентностей. Лінійно-концентричний принцип розміщення матеріалу у навчальних програмах дозволяє формувати і закріплювати ключові освітні компетентності в усіх класах початкової школи.

Відомо, що тільки активна взаємодія 3 природою здатна виховати найкращі людські якості. Тому природнича освітня галузь має найбільше можливостей для формування таких ключових компетентностей як вільне володіння державною мовою, уміння вчитися та можливість одержання інформації, співробітництво, здоров'язберігаюча, громадянська та соціальна. Система предметних компетенцій, що формуються при вивченні природознавства, відповідає його інтегративному змісту.

Л. Г. Савлучинська визначила наступні педагогічні умови формування природознавчої компетентності учнів початкових класів на уроках природознавства: впровадження на уроках елементів проблемного навчання; проведення дидактичних ігор природничо-екологічного змісту; проведення інтегрованих уроків для засвоєння системи інтегрованих знань про природу [8]. Н. М. Редчиць важливого значення надає методу проектів та інформаційно-комунікаційним технологіям, які формують практично всі життєві компетентності [7]. Провідна роль у вивченні довкілля належить спостереженням, експериментам, екскурсіям, природоохоронній та проектній діяльності школярів.

При формуванні природознавчої компетентності в інклюзивних класах ми надавали перевагу спостереженням із елементами дослідження, практичним роботам, дослідам, екологічному прогнозуванню, впроваджуючи елементи диференційованого та індивідуалізованого навчання.

Спостереження залишається основним методом вивчення природознавства в початковій школі. Розвиваючи дослідницькі уміння при вивченні навчального предмета «Я досліджую світ», слід прагнути викликати у дітей спочатку допитливість, а пізніше - стійкий інтерес до 
спостережень і на цій основі сформувати відповідальне ставлення до всього живого, що потребує нашої допомоги та захисту. Спостереження передбачають розвиток уявлень учнів молодшого шкільного віку про об'єкти та явища природи, встановлення зв'язків між неживою і живою природою, формування бережливого ставлення до природи і вироблення навичок екологічно доцільної поведінки у довкіллі. Спостереження за об'єктами та явищами природи розвивають мислення, розумові здібності, кмітливість, критичність, самостійність, спостережливість і сприяють оволодінню методами природоохоронної роботи. Спостереження дітей за рослинами і тваринами та догляд за ними допомагають усвідомити, що живі організми - це природні об’єкти, які потребують нашої допомоги та турботи; дають змогу упереджувати жорстокість у взаємодії з ними.

Етапи спостереження доцільно поєднувати з етапами формування природничих понять у дітей з особливими освітніми потребами.

На першому етапі необхідно забезпечити мотиваційну та текстову підготовку учнів до засвоєння природничих понять на уроках природознавства. Для цього у навчальному процесі необхідно використовувати цікаву інформацію, яскраві приклади та факти, які стимулюють пізнавальні інтереси учнів і показують практичне значення теми.

Формування позитивної мотивації за змістом навчального матеріалу бажано забезпечувати постійним використанням пізнавального матеріалу: різнопланової наочності, загадок, віршів, ігор, хвилинок релаксації тощо.

На етапі організації чуттєвого сприймання ознак предметів або явищ природи необхідно, щоб об'єкти, які сприймаються, складали чуттєвий досвід молодших школярів. Це є необхідною умовою для засвоєння природничих понять. Тому обов'язковим елементом цього етапу має бути чуттєве сприймання, тобто відображення об'єктів та явищ природи у свідомості дітей. Таке свідоме сприймання доцільно забезпечувати ретельним відбором і демонструванням об'єктів, які за своїм змістом відповідають поняттям, що формуються під час спостережень.

Третій етап - організація розумової діяльності, яка спрямована на виділення характерних ознак поняття, що вивчається. Цей етап можна починати, коли є достатньо матеріалу для мислення: уявлення, конкретні факти, ознаки предметів тощо. На цьому етапі необхідно навчати молодших школярів порівнювати.

На етапі вербалізації суті поняття необхідно продовжувати формувати природничі поняття методом узагальнення. Така робота проводиться шляхом повторення усіх істотних ознак певного явища або предмета за запитаннями учителя.

На етапі вербалізації та узагальнення знань доцільне використання різноманітних ігор та групової роботи. Так, застосування ігор «Які ти знаєш рослини?», «Пізнай тварину», «Чий плід?», «В кого дітки з цієї гілки?» під час екскурсій у природу дають змогу залучити дітей до активного пізнання природи та сприяють вихованню бережливого ставлення до неї.

Для формування природознавчої компетентності велику значущість мали екскурсії у природу, де молодші школярі спостерігали за об’єктами живої і неживої природи. Кожна екскурсія включала самостійну роботу, виконуючи яку учні систематизували знання з вивченої теми. Усі види екскурсій формують в учнів природничі поняття та розвивають у них спостережливість. Екскурсії в природу роблять процес навчання цікавим, допомагають молодшим школярам краще орієнтуватися в довкіллі, збагачують їх словник, розвивають мовлення. Об'єкти і явища природи привертають увагу, цікавлять і збуджують допитливість, розвивають спостережливість школярів; допомагають їм навчитися відчувати прекрасне, викликають у них шанобливе ставлення до природи.

В ході екскурсії задіяні всі органи чуття, це полегшує сприйняття, в той же час роблячи його більш комплексним і всебічним: активізується зорова, вербальна і моторна активність молодших школярів. Спостерігаючи природні процеси і явища живої і неживої природи, діти 3 особливими освітніми потребами вчяться аналізувати, виявляти основні ознаки та відслідковувати зв'язки між природними об'єктами.

Свідоме сприймання результатів досліду буде залежати від правильно організованих спостережень, пояснення вчителя, саме вони підвищують сприймання і активність дітей. Ми керувались тим, що уміння спостерігати формується поступово, тому для розвитку спостережливості забезпечували цілеспрямоване сприйняття - демонстрування дослідів. Під час спостереження увага школярів акцентувалась на характерні ознаки, що допомагало їм отримати детальну інформацію про властивості речовин, які досліджувалися. При проведенні спостережень необхідно встановити взаємозв'язки 3 вивченим раніше матеріалом, що забезпечить свідоме засвоєння нових знань молодшими школярами. 
Проблемне навчання базувалося на організації навчального процесу, який передбачає створення проблемної ситуації та активну самостійну діяльність учнів у ії розв’язанні, що веде до грунтовного засвоєння й закріплення наукових положень, розвиває творче мислення, здатність до самостійної діяльності. Уроки природознавства в початковій школі мають значні можливості для створення проблемних ситуацій. Проблемна ситуація завжди базується на суперечності [8]. Молодші школярі розв'язували проблемні ситуації, застосовуючи набуті знання, частково-пошукову діяльність та організацію дослідницької діяльності шляхом спостереження за природним довкіллям або за результатами самостійного досліду. Керуючи пошуковою діяльністю учнів, ми вдало підібрали комплекс проблемних інтегрованих завдань, які різнилися за ступенем складності.

Теорія проблемного навчання передбачала необхідність стимуляції творчої діяльності молодших школярів та надання їм належної допомоги у процесі дослідної діяльності, а також визначала засоби реалізації через викладання навчального матеріалу спеціальними методами. Основу теорії складала ідея використання творчої діяльності дітей молодшого шкільного віку шляхом розв'язання проблемних завдань та активізації їх пізнавальної діяльності.

Проблемне навчання передбачало:

- створення учням проблемної ситуації, тобто постановка навчально-проблемного завдання;

- усвідомлення, розуміння та розв'язання учнями проблеми, в процесі яких відбувається опанування ними узагальненими засобами набуття нових знань;

- використання цих засобів для розв’язання конкретних завдань.

Постановка навчальної проблеми стимулювала творчу діяльність учнів і забезпечувала надання їм допомоги у процесі дослідної діяльності. За рахунок цього в учнів активізувалися пізнавальні інтереси та уся пізнавальна діяльність

Для формування в учнів перших $\mathrm{i}$ других класів природничих компетентностей доцільно використовувати ігрові методи: ігри-заняття, ігри-вправи, сюжетні та дидактичні ігри. Вони забезпечують цікавий процес навчання та сприяють формуванню загальнонавчальних умінь і навичок. Основна мета ігрових методів - допомогти дітям вивчити об'єкти природи, навчитися берегти природне довкілля, надати повсякденним ситуаціям гуманістичного спрямування. Активізації пізнавальної активності особливо сприяють сюжетні ігри та вправи 3 природничим матеріалом.

Ігри, які спрямовані на розвиток здатності молодших школярів розрізняти зовнішні ознаки і властивості природних об'єктів і явищ, розвивають спостережливість, розширюють коло сприйняття естетично цінних об'єктів природи, сприяють формуванню у дітей потреби спілкування з природою («Впізнай мене», «Яких кольорів більше?», «Асоціації», «Впізнай за голосом», «Що де росте?», «Хто як рухається», «Зоопарк», «Чарівні листки», «Що змінилось?», «Картина за вікном» [8].

Ігри, пов'язані із вдосконаленням уміння ставити себе на місце іншого, виявляти співчуття, орієнтовані на формування уміння розрізняти і розуміти емоційні стани товаришів, однолітків, дорослих, пізніше - звірів, птахів, рослин; створювати образи, передавати їх за допомогою різних засобів художньої виразності («Визнач настрій», «Дикі та домашні тварини», «Незавершене оповідання», «Незвичайна ситуація», «Озвучення картини» тощо).

Ігри, які сприяють розвитку в школярів сприйнятливості до зовнішньої виразності в природі та здатності виявляти співчутливі реакції стосовно до антропоморфізованих природних об'єктів, спрямовані на закріплення знань й умінь, набутих під час виконання ігор перших двох груп. Під час ігор «Дивна подорож до лісу», «Гра в лісових мешканців», «Подорож до країни Див» тощо молодші школярі проявляли чутливе ставлення до природи, здатність до емоційного співпереживання, створення образів, естетичної оцінки природних об'єктів і явищ [8].

Використання проектної технології передбачало врахування індивідуальних особливостей учнів. Усі етапи проектної діяльності контролювалися, оскільки теоретичних знань і практичних умінь у дітей молодшого шкільного віку недостатньо. Працюючи над проектами, учні початкової школи навчалися працювати в колективі, відповідати за виконану роботу, аналізувати результати своєї діяльності, відчувати себе членом команди, що особливо важливо в умовах інклюзивного навчання.

Індивідуалізація й диференціація навчання - це дві сторони одного і того ж процесу врахування й розвитку індивідуальних особливостей кожного учня, тому їх потрібно розглядати у взаємозв'язку. Диференціація - процес забезпечення необхідних умов для максимального розвитку вмінь, навичок, здібностей та задоволення пізнавальних інтересів у процесі засвоєння змісту навчальної програми. 
Диференційований підхід у навчанні на інтегрованих уроках дає можливість ставити перед учнями комплексні навчальні завдання, які передбачають творчий пошук та створюють передумови для розвитку природознавчої компетентності.

Основними дидактичними умовами впровадження засобів інтеграції та диференціації на уроках природознавства $є$ :

- орієнтація на психологічний стан та конкретний дефект молодших школярів, їх готовність до сприйняття певної інформації;

- значна свобода учителів у варіюванні навчальними завданнями протягом певних часових інтервалів та використання педагогом у своїй діяльності цілісних навичок і умінь учнів, які повинні бути сформовані в процесі навчальної роботи;

- відмова від використання оцінного методу порівняння 3 іншим, який породжує нездорову конкуренцію, конфронтацію у міжособистісних стосунках та психологічні комплекси на внутрішньоособистісному рівні;

- інтегрування навчально-виховного процесу при збереженні базового освітнього компоненту за рахунок уніфікації матеріалу навчальних дисциплін, об'єднання різних освітніх завдань в одному предметі, встановлення зв'язків шляхом включення до навчального плану принципово нових навчальних дисциплін інтегрованого характеру.

Загальні рекомендації впровадження елементів індивідуалізованого навчання в умовах інклюзивної системи навчання передбачають: використання на уроці елементів технологій індивідуалізованого навчання; подолання індивідуальних недоліків у знаннях, уміннях i навичках, в процесі мислення; надання кожній дитині молодшого шкільного віку індивідуальної педагогічної допомоги; облік і корекція недоліків сімейного виховання, а також нерозвиненості сфери мотивації, слабкості вольових процесів; оптимізація навчального процесу стосовно здібностей учнів (творча діяльність, поєднання класної і позакласної роботи); надання свободи вибору елементів процесу навчання; формування загальнонавчальних умінь і навичок; формування адекватної самооцінки учнів; використання технічних засобів навчання; підтримка здібних та обдарованих дітей.

Проведення інтегрованих уроків передбачало включення у навчальний процес на одному уроці тем з різних предметів. Під час повторення та закріплення знань, спрямованих на формування в учнів природознавчої компетентності, ми проводили інтегровані уроки, поєднуючи природознавство з іншими навчальними предметами.

Інтегрований підхід до навчання задовольняє особливості початкового навчання та реалізацію поставлених цілей в умовах інклюзивної освіти. Мета навчання на інтегративній основі - дати цілісне уявлення про природне довкілля, сприяти підвищенню пізнавальної активності молодших школярів, забезпечити самовираження, самореалізацію та розвиток гармонійної особистості з метою адаптації ї̈ до соціуму.

Для з'ясування рівня сформованості природознавчої компетентності в учнів третього класу нами було проведено констатувальний експеримент. 3 цією метою на матеріалі природознавства, який вивчався у другому класі, нами була проведена контрольна робота, яка включала тестові завдання.

За кількістю відповідей на контрольній роботі відповідно до розроблених критеріїв дослідницькі уміння учнів, знання молодших школярів з предмета, навички спостереження за природним довкіллям та наявність у них мотивації на відповідальне ставлення до природи нами були виділені три рівні сформованості природознавчої компетентності в учнів : низький, середній та високий.

Рівні сформованості природознавчої компетентності були виділені за кількістю правильних відповідей: одна - п’ять правильних відповідей - низький рівень, шість - вісім правильних відповідей - середній рівень, 9-10 правильних відповідей - високий рівень.

Результати констатувального експерименту показали, що в обох класах високий рівень сформованості природознавчої компетентності має незначна кількість учнів: у контрольному класі - два учні $(11,1 \%)$, в експериментальному - три учні (17,6\%). Переважна більшість молодших школярів має середній рівень (50,0\% у контрольному класі та 47,1\% у експериментальному), значна кількість учнів із низьким рівнем (38,9\% і 35,3\% відповідно). Це свідчить про те, що рівні сформованості природознавчої компетентності учнів в обох класах приблизно однакові.

Для перевірки на практиці дидактичних умов формування природознавчої компетентності у процесі вивчення школярами молодших класів предмета «Природознавство» в експериментальному класі нами був проведений формувальний експеримент, який передбачав застосування власної методики, яка базувалась на систематичному застосуванні 
елементів індивідуалізації, диференціації та інтеграції при впровадженні на уроках природознавства елементів проблемного навчання, проведення дидактичних ігор, екскурсій, практичних робіт, спостережень.

Провівши роботу, спрямовану на покращення формування в учнів експериментального класу природознавчої компетентності, нами було проведено повторну контрольну роботу в обох класах, яка включала тестові завдання природничої тематики.

Результати контрольної роботи на формувальному етапі експерименту засвідчили, що у контрольному класі кількісні показники зазнали незначних змін. Так, кількість учнів із низьким рівнем зменшилась на 5,5\%. Кількість учнів із середнім рівнем збільшилась на 5,5\%, а кількість учнів з високим рівнем зросла на $11,1 \%$.

В експериментальному класі кількісні показники зазнали більших змін. Кількість учнів із низьким рівнем сформованості природознавчої компетентності зменшилася на $23,5 \%$. Кількість учнів із середнім рівнем зменшилася на $11,1 \%$, кількість учнів із високим рівнем зросла на $35,3 \%$. Результати дослідження засвідчили високу ефективність застосування експериментальної методики, яка базувалася на запропонованих дидактичних засобах формування природознавчої компетентності молодших школярів в умовах інклюзивного навчання.

Висновки. Компетенція завжди пов'язана 3 певним видом діяльності людини, а компетентність - якість особистості, ії певне надбання, що грунтується на знаннях та досвіді.

Природознавчу компетентність слід розглядати із позиції інтерактивного підходу. Дидактичними умовами формування природознавчої компетентності у молодших школярів в умовах інклюзивного навчання $є$ впровадження на уроках природознавства інноваційних технологій, які базуються на індивідуалізації, диференціації та інтеграції навчального процесу.

Інтеграція в природничій освітній галузі, на нашу думку, є однією з найперспективніших інновацій. Завдяки їй закладаються нові умови діяльності молодших школярів і вчителів, що забезпечує ефективні умови формування природознавчої компетентності.

\section{ЛІТЕРАТУРА}

1. Головань М. С. Компетенція та компетентність: порівняльний аналіз понять / М. С. Головань // Педагогічні науки: теорія, історія, інноваційні технології. - 2011. - № 8. - С. 224-233.

2. Грошовенко О. П. Формування природознавчої компетентності молодших школярів / О. П. Грошовенко, Л. А. Присяжнюк // Збірник наукових праць [Херсонського державного університету]. Педагогічні науки. - 2017. - Вип. 78(1). - С. 74-79.

3. Державний стандарт початкової загальної освіти [Електронний ресурс]. - Режим доступу : http://osvita.ua/doc/files/news/87/8793/01_ukr.pdf.

4. Лейко С. В. Поняття «компетенція» та «компетентність»: теоретичний аналіз / С. В. Лейко // Педагогіка. - 2013. -№ 8. - С. 128-135.

5. Можаєва О. М. Формування і розвиток основних компетентностей особистості в початковій школі / О. М. Можаєва // Початкова освіта. - 2009. - № 32. - С. 21-23.

6. Нова українська школа. Електронний ресурс. Режим посилання : https://mon.gov.ua/ua/tag/novaukrainska-shkola.

7. Редчиць Н. М. Шляхи формування природознавчої компетентності молодших школярів на уроках природознавства / Н. М. Редчиць // Матеріали Х Всеукраїнської практично-пізнавальної конференції «Наукова думка сучасності і майбутнього» (5-13 квітня 2017 р.). -Дніпро, 2017. - С. 22-28.

8. Савлучинська Л. Г. Формування природознавчої компетентності учнів початкових класів на уроках природознавства / Л. Г. Савлучинська // Наука і освіта. - 2013. - № 6. - С. 111-114.

9. Стратегія реформування освіти в Україні: Рекомендації з освітньої політики. - К. : «К.І.С.», 2003. - 296 с.

10. New Webster's Dictionary and Thesaurus of the English language: Lesicon Publication, 1993. $-1150 \mathrm{p}$. 